\title{
Genotoxicity Assessment of Contaminated Drinking Water Sources in a Rural Community in Edo State of Nigeria
}

\author{
D. I. Olorunfemi ${ }^{*}$, O. P. Olorunfemi², I. E. Agbozu ${ }^{3}$ \\ ${ }^{1}$ Department of Plant Biology and Biotechnology, University of Benin, Benin City, Nigeria \\ ${ }^{2}$ Department of Animal and Environmental Sciences, University of Benin, Benin City, Nigeria \\ ${ }^{3}$ Department of Environmental Sciences, Federal University of Petroleum Resources, Effurun, Nigeria \\ Email: udanfem@gmail.com
}

Received December 2013

\section{Abstract}

In most rural settlements in Nigeria, provision of potable water for drinking and domestic purposes is a big challenge; therefore analysis of drinking water is of great importance as contaminated water jeopardizes both the physical and social health of all people. Water samples were obtained during the dry and wet seasons from a borehole and a man-made lake constructed through self-help effort in Obazuwa community in Ovia North East Local Government Area of Edo State, Nigeria. They were analyzed for physicochemical parameters and subjected to cyto-genotoxic evaluation using the Allium cepa assay. Results of the physicochemical analysis showed that most of the parameters $\mathrm{(pH}$, chromium, copper, chlorides, nickel, iron, zinc, cadmium, lead and manganese) of the lake water in both seasons exceeded World Health Organisation (WHO) permissible limits. Total heterotrophic bacteria and $E$. coli were present with dry season water samples having higher amounts. Compared to the control, the mitotic index decreased significantly $(p<0.05)$ in the water samples and were characterized by a number of chromosomal aberrations notably bridges, fragments, sticky chromosomes, disoriented chromosomes, and micronuclei in significant amounts and these were more pronounced in water samples obtained during the dry season. The findings in this study are of public health relevance as access to safe water is a fundamental human need and therefore, a basic human right.

\section{Keywords}

Man-Made Lake; Obazuwa Community; Physicochemistry; Microbial Load; Genotoxicity

\section{Introduction}

One of the primary goals of the World Health Organization (WHO) and its Member States is that "all people,

\footnotetext{
*Corresponding author.
}

How to cite this paper: Olorunfemi, D. I. et al. (2014). Genotoxicity Assessment of Contaminated Drinking Water Sources in a Rural Community in Edo State of Nigeria. Journal of Geoscience and Environment Protection, 2, 52-59. 
whatever their stage of development and their social and economic conditions, have the right to have access to an adequate supply of safe drinking water" (WHO, 2011). Although Nigeria is known to be endowed with abundant water resources, the availability of potable water is a problem in many parts of the country. The provision of pipe borne potable water is the primary responsibility of the Federal, State and Local Governments but unfortunately, access to drinking water is grossly inadequate both in quantity and quality (Onokerhoraye, 1995). As a result, most rural dwellers result to streams, hand-dug wells, rivers, lakes for their drinking water supply. These water sources are under threat from pollution from either human life style manifested by the low level of hygiene practiced or through non-point source when already polluted water in the area enters into the ground water body by lateral or side movement (Wright et al., 2004). Obazuwa community is a rural settlement located within latitude $5^{\circ} \mathrm{E}, 6^{\circ} \mathrm{E}$ and longitude $5^{\circ} \mathrm{N}, 7^{\circ} \mathrm{N}$, in Ovia North-East Local Government Area of Edo State whose main sources of drinking water are a man-made lake and an unreliable borehole, therefore the community depends mainly on the lake constructed by the inhabitants through self-help. The community is characterized by two major tropical climates marked by two seasons (rainy and dry) which run from April to September and October to March respectively.

The most effective way to protect the quality of drinking water is through consistent monitoring of the drinking water supply (Yassi et al., 2001). The complexity of contaminated water makes it almost impossible to carry out a hazard assessment based on physicochemical analysis alone, therefore, a comprehensive approach involving the use of plant bioassays alongside chemical and microbial analysis has been advocated for hazard assessment in toxicity screening of contaminated water (Arkhipchuk et al., 2000). The Allium test, a higher plant genetic assay has been accepted as an excellent and alternative first-tier indicator for safety evaluation of cytogenetic and mutagenic effects of drinking water and environmental pollutants (Ma et al., 1985; Fiskesjö, 1993, 1997). Currently, there is no documentation on the physicochemical, microbial and cytogenotoxicological evaluation of the drinking water sources in this rural community, therefore, this study was undertaken to investigate the efficiency of the combined methods in monitoring the drinking water sources in the rural settlement.

\section{Materials and Methods}

\subsection{Collection of Water Samples}

Water samples for the study were collected in March and July 2012. Plate 1 (a-c) shows the site of water collection: lake water during the dry season, lake water during the wet season and borehole water respectively. The lake water samples were collected at different depths from five random points within the lake. For the borehole, sampling protocols described by Claaasen (1982), Barcelona et al. (1985), and APHA (2005) were strictly adhered to during sampling collection. The nozzle of the borehole was swabbed with cotton wool soaked in $70 \%$ (v/v) ethanol and flamed for 2 - 3 min. Samples were collected using washed and sterilized plastic containers after running water to waste for 4 - 5 min. In both cases, samples were taken in triplicates from each sampling point aseptically into plastic containers and kept in an ice chest and stored in the refrigerator at $4^{\circ} \mathrm{C}$ and analysed within $24 \mathrm{~h}$ of collection.

\subsection{Physicochemical Analysis of the Water Samples}

Water samples, together with control, were analysed for a number of standard physicochemical properties, including nitrates, chlorides and phosphates, according to methods described by APHA (2005). Nine metals namely lead, copper, cadmium, chromium, iron, zinc, nickel, magnesium and manganese were analysed in the water samples according to standard analytical methods (USEPA, 1996; APHA, 2005) using an atomic absorption spectrometer (AAS) (PerkinElmer A Analyst 100). The metal standards were prepared to known concentrations, labelled, and kept inside plastic bottles that were pre-cleansed with concentrated nitric acid and distilled water. For microbial analysis, the techniques employed were estimation of total heterotrophic bacteria (THB) by plate count technique and estimation of coliform bacilli by MPN presumptive test (APHA, 1998).

\subsection{Allium cepa Assay}

The purple variety of average sized onion bulbs, Allium cepa L. (about 30 g, 15 - 22 mm diameter) were purchased from a local market in Benin City and the same batch of bulbs was used throughout. They were sun-dried for two weeks and the dried roots present at the base of the onion bulbs were carefully shaved off, with a sharp 
razor blade to expose the fresh meristematic tissues. The bulbs were then placed in freshly prepared distilled water to protect the primordial cells from drying up. To account for a number of bulbs in the population that would be naturally slow or poor growing, seven replicate bulbs were used for each test sample and control (tap water) and the best five bulbs were chosen for examination. The bulbs were removed from the distilled water and placed on a blotting paper to remove excess water.

For the root growth inhibition evaluation, seven onion bulbs were utilized for each water sample and the control (tap water). The base of each of the bulbs was suspended on the water sample inside $100 \mathrm{ml}$ beakers in the dark for $72 \mathrm{~h}$. Test samples were changed daily. At the end of the exposure period, the roots of five onion bulbs with the best growth were removed with a forceps and their lengths measured (in $\mathrm{cm}$ ) with a metre rule. The percentage root growth inhibition in relation to the negative control was then calculated.

For the evaluation of induction of chromosomal aberration, five onion bulbs were suspended in the water samples and the control for 48 h., at the end of which root tips from these bulbs were cut and fixed in ethanol:glacial acetic acid $(3: 1, \mathrm{v} / \mathrm{v})$. These were hydrolyzed in $1 \mathrm{~N} \mathrm{HCl}$ at $65^{\circ} \mathrm{C}$ for $3 \mathrm{~min}$ after which they were washed in distilled water. Two root tips were then squashed on each slide, stained with acetocarmine for 10 min and cover slips carefully lowered on to exclude air bubble. The cover slips were sealed on the slides with clear fingernail polish to prevent drying out of the preparation by the heat of the microscope. Six slides were prepared for each water sample and the control out of which five (at 1000 cells per slide) were analyzed at $\times 1000$ magnification for induction of chromosomal aberrations. The mitotic index and the frequency of aberrant cells (\%) were calculated following methods of previous studies (Olorunfemi et al., 2011).

\subsection{Statistical Analysis}

The means, with 95\% confidence limits and the standard errors for results of the root inhibition and chromosome aberrations of each water sample were calculated. Data were expressed as Mean \pm Standard Error of Mean (SEM). Differences between the control and the different water samples were analyzed by means of the Student's unpaired t-test. $P$ values of $\leq 0.05$ were considered to be statistically significant. All statistical analyses were carried out using SPSS ${ }^{\circledR} 14.0$ statistical package.

\section{Results and Discussion}

\subsection{Physicochemical Analysis}

The results of the physical and chemical analysis of the test water samples collected are presented in Table $\mathbf{1}$. The pH value was slightly basic (7.59) in the borehole during the wet season and acidic (5.15) in the lake during the dry season. The results revealed that the level of parameters such as turbidity, lead, nickel, chromium, in the lake water in the dry season compared with international (WHO) and national (SON) standards exceeded permissible limits.

The consumption of unsafe water has been implicated in a number of health risks including cancer of the digestive and urinary tract, human gastrointestinal irritation and laxative effects (Okonko et al., 2008; Sia Su, 2007) and chromosome aberration and DNA damage enhancing genetic changes in somatic cells that can result in decreased cell survival or transformation and eventual reproductive abnormalities (Shugart et al., 1992, Fawole et al., 2008, Olorunfemi et al., 2013). All the water samples were turbid with elevated levels of heterotrophic bacteria and E. coli, some of which could produce toxins. Coupled with the acidic nature of the lake water in both seasons and the slightly alkaline nature of the borehole water in the wet season with the high levels of inorganic compounds and heavy metals, the water sources would not only be unpalatable in taste but could also pose significant health risk to this community as have been found elsewhere (Gupta et al., 2001; Sia Su, 2005).

\subsection{Cytogenotoxic Evaluation of Allium Test}

Compared to the control, there was gross inhibition of root growth in the water samples in significant $(p<0.05)$ amounts. Higher root growth rates were recorded in the water samples obtained in the wet than those collected in the dry season, for example, the mean root length of $A$. cepa grown in the lake water sample during dry season was $4.36 \pm 0.55 \mathrm{~cm}$ and $4.71 \pm 0.64 \mathrm{~cm}$ in the wet season while the mean root length was $3.40 \pm 0.54 \mathrm{~cm}$ and $4.85 \pm 0.77 \mathrm{~cm}$ for borehole water samples during dry and wet seasons respectively (Figure 1). Comparative analysis of microscopic parameters shows that the mitotic indices of the test water samples during wet season Table 1. Physicochemical properties of water samples obtained from the study site (Obazuwa) during dry and wet seasons. 


\begin{tabular}{|c|c|c|c|c|c|c|}
\hline Parameters & $\begin{array}{l}\text { Lake water } \\
\text { (Dry season) }\end{array}$ & $\begin{array}{l}\text { Lake water } \\
\text { (Wet season) }\end{array}$ & $\begin{array}{l}\text { Borehole water } \\
\text { (Dry season) }\end{array}$ & $\begin{array}{l}\text { Borehole Water } \\
\text { (Wet season) }\end{array}$ & $\begin{array}{c}\text { WHO (2006) } \\
\text { Limit }\end{array}$ & $\begin{array}{l}\text { SON (2007) } \\
\text { Limit }\end{array}$ \\
\hline $\mathrm{pH}$ & 5.15 & 5.80 & 6.45 & 7.59 & $6.5-9.5$ & $6.5-8.5$ \\
\hline Turbidity & 13.1 & 10.5 & 11.3 & 10.1 & - & - \\
\hline Conductivity & 1350 & 1540 & 1420 & 1040 & - & - \\
\hline Total Hardness & 263.33 & 326.66 & 236.66 & 216.66 & 500 & 150 \\
\hline Nitrates & 100.9 & 99.3 & 50.8 & 29.0 & 50 & 50 \\
\hline Phosphates & 145.25 & 123.25 & 80.05 & 97.65 & - & - \\
\hline Magnesium & 163.9 & 170.8 & 59.5 & 71.3 & - & 0.20 \\
\hline Chloride & 798.75 & 763.25 & 745.50 & 305.75 & - & 250 \\
\hline Manganese & 4.1 & 5.9 & - & 0.1 & - & 0.20 \\
\hline Nickel & 0.2 & 0.3 & - & - & 0.02 & 0.02 \\
\hline Cadmium & 0.1 & 0.2 & - & - & 0.003 & 0.003 \\
\hline Lead & 0.2 & 0.1 & 0.1 & - & 0.01 & 0.01 \\
\hline Iron & 11.1 & 15.3 & - & 1.3 & - & 0.3 \\
\hline Zinc & 21.6 & 30.5 & 2.2 & 2.6 & 0.01 & 3.0 \\
\hline Chromium & 2.4 & 3.0 & - & - & 0.05 & 0.05 \\
\hline Copper & 2.8 & 1.8 & 1.8 & 0.1 & - & 0.1 \\
\hline Silver & 0.2 & 0.1 & - & - & - & - \\
\hline TH Bacteria & 5.4 & 2.6 & 4.1 & 3.3 & 0 & 0 \\
\hline Coliform Organisms & 10 & 2.0 & 6.4 & 4.6 & 0 & 0 \\
\hline
\end{tabular}

Plate 1 (a-c) shows the site of water collection: lake water during the dry season, lake water during the wet season and borehole water respectively.
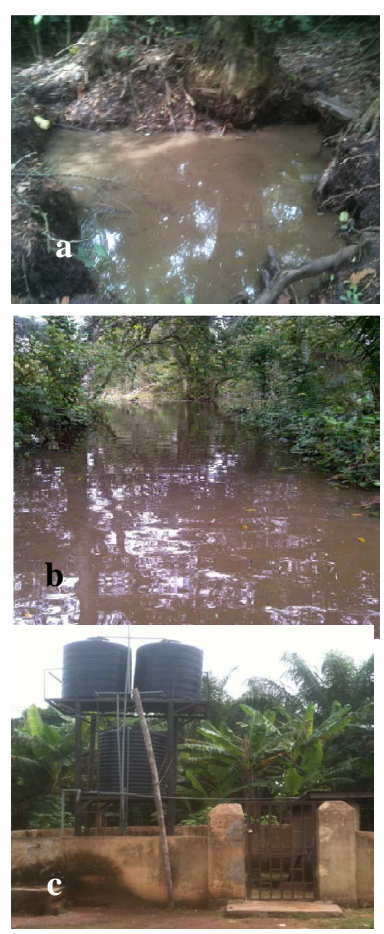

Plate 1. The study site: Obazuwa man-made lake during the (a) dry season (b) wet season (c) the only borehole located in Obazuwa community from where water samples were collected. Photo Credit: Dr. D. I. Olorunfemi. 


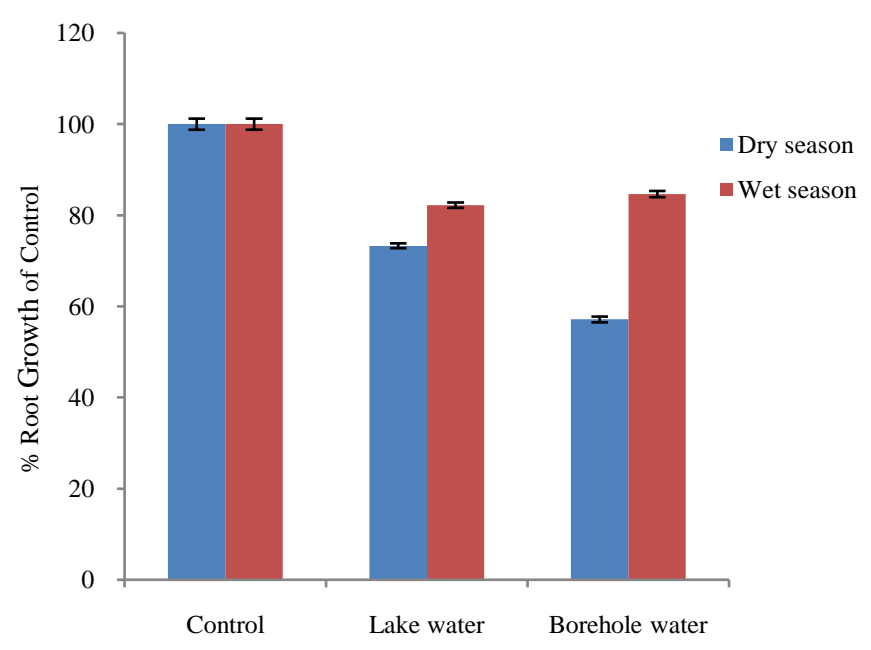

Figure 1. Percentage root growth of Allium cepa roots exposed to the test water samples during dry and wet season.

was greater than those of the dry season in the water samples obtained from both the lake and borehole while the percentage aberrant cells were greater during the dry season (Figures 2 \& 3). Chromosomal aberrations were induced on exposure to all the test water samples. The most frequent aberrations were chromosome stickiness and anaphase bridges (Plate 2).

There is a linear relationship between macroscopic and microscopic parameters for all the water samples. In $A$. серa, whenever there is root growth inhibition, there is always reduction in the number of dividing cells; the lower the mitotic index, the more toxic the waste water, chemical or pollutant (Fiskesjö, 1997; Babatunde \& Bakare, 2006). The direct relationship between the macroscopic growth and microscopic parameters in this study may infer that the heavy metals in the water samples are responsible for the aberrations observed in the root tip cells of the onion. The presence of trace metals ( $\mathrm{Cr}, \mathrm{Fe}, \mathrm{Mn}, \mathrm{Zn})$ and other inorganic compounds at varying concentrations in the water samples may be responsible for the root growth inhibition and chromosome aberrations observed in the A. cepa root meristems. The individual and/or complex interactions of these metals may have caused the observed cytogenotoxic effects. The inhibition of mitotic index has been attributed to the effects of environmental chemicals on DNA/protein synthesis of the biological systems (Chauhan et al., 1998). Anderson (1985) reported that binary mixture of $\mathrm{Cr}$ and Ni affected mitotic spindles leading to chromosomal aberration in exposed A. сера. More so, some of these metals ( $\mathrm{Fe}, \mathrm{Cr}$ and $\mathrm{Zn}$ ) in their combined states have been reported to induce high percentage of micronucleated red blood cells and nuclear abnormalities in newt larvae (Godet et al., 1993).

Most of the observed cytotoxic/genotoxic effects in the root meristems in A. cepa were possibly induced by the chemicals and microorganisms in the water samples and this may present a direct or indirect risk to living organisms. The presence of laggards and stickiness and chromosome bridges are regarded as mitotic irregularities induced by pollutants (Zhang \& Yang, 1994). Sticking of chromosomes probably occurs due to degradation or depolymerization of chromosomes DNA (Grant, 1982) or as a result of DNA condensation and stickiness of inter-chromosome fibres (Schneiderman, 1971). Stickiness reflects high toxicity of substance as well as ireversibility of the change while acentric fragments in anaphase is the result of chromosome or chromatids interruptions, indicating interference with DNA. Bridges probably occur by the interruption and joining chromosomes or chromatids (Turkoglu, 2007), or as a result of chromosome stickiness, or it may be ascribed to unequal translocation or inversion of chromosome segments (Gömürgen, 2005).

In conclusion, although the study did not obtain documented evidence on the incidence of major water borne disease outbreak in the community, notwithstanding, the concentrations of physicochemical constituents and microbial load of the water samples were higher than permissible national and international limits. Furthermore, the classical Allium chromosomal aberration conventional test used in this study to detect environmental clastogens revealed reduced mitotic index and chromosome aberrations in the water samples. The observed frequencies of chromosomal bridge, sticky and laggard chromosomes are indicators of chromosome damage. The combination of these methods for evaluating drinking water quality in a developing country like Nigeria is relatively 


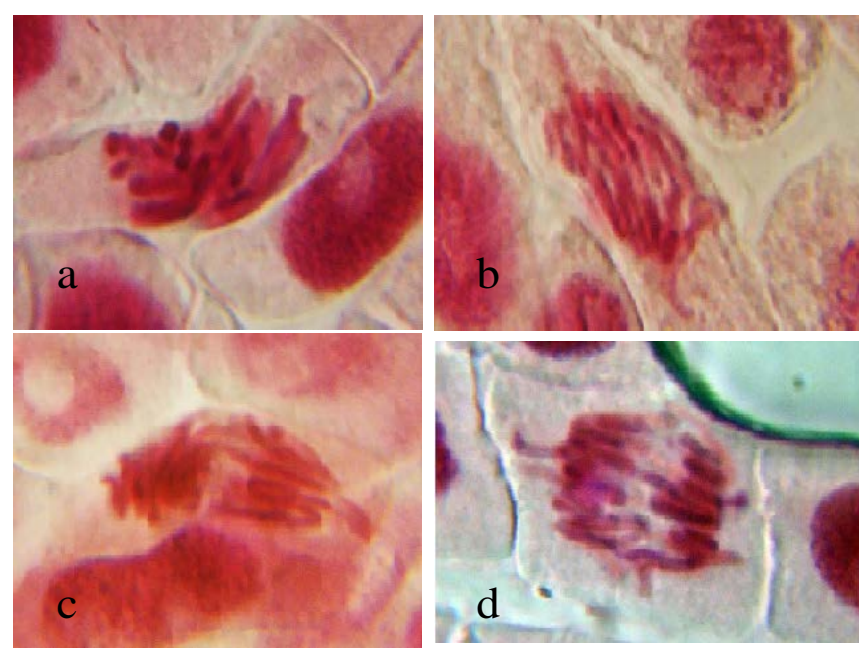

Plate 2. Chromosomal abnormalities induced in A. cepa root tips grown in the water samples (a) sticky chromosome (b) multiple bridges (c) polar deviation (d) vagrant chromosomes with breaks.

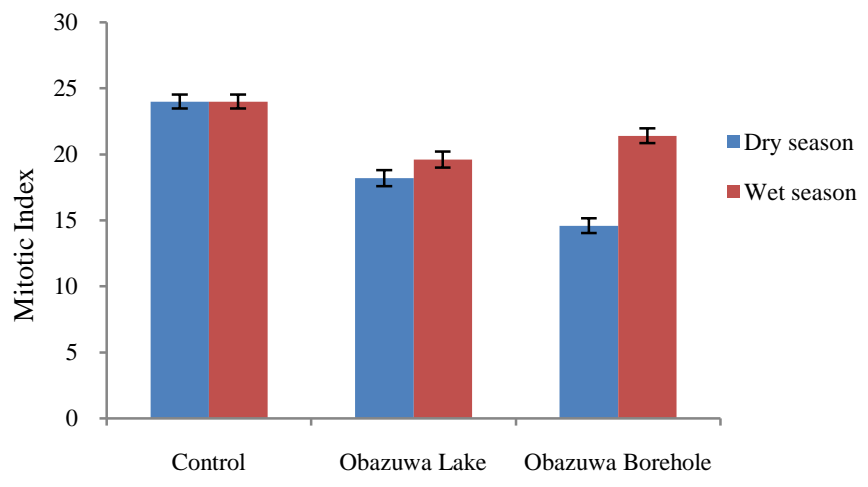

Figure 2. Effect of water samples on mitotic index of $A$. cepa.

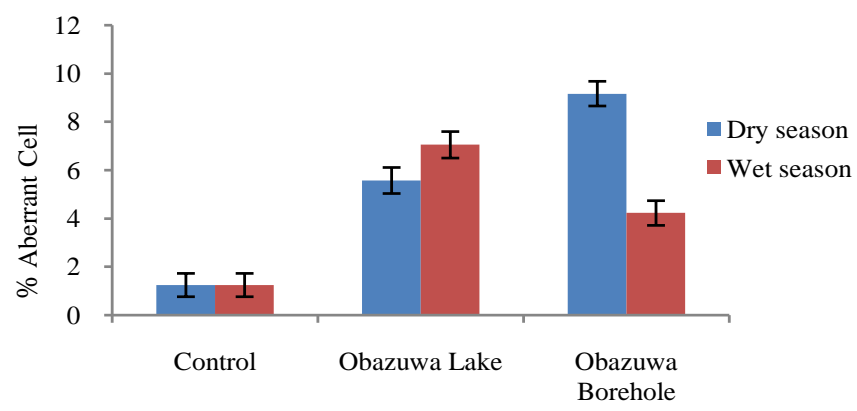

Figure 3. Effect of water samples on chromosomal aberration in $A$. сера.

cheap and easy. We advocate that they should be used alongside each other for hazard assessment in toxicity screening of contaminated water. We also strongly recommend that the results obtained from this study should be considered a signal that water obtained from these water sources in Obazuwa community may constitute a risk to human health and therefore need proper purification treatments before they become safe for consumption.

\section{References}

American Public Health Association (APHA) (1998). Standard Methods for the Examination of Water and Wastewater (18th 
ed., pp. 45-60). Washington DC: American Public Health Association.

American Public Health Association (APHA) (2005). Standard Methods for the Examination of Water and Wastewater (21st ed., 1220 p). Washington DC: American Public Health Association.

Anderson, O. (1985). Evaluation of the Spindle Inhibition Effects of $\mathrm{Ni}^{2+}$ Quantitation of Chromosomal Super Condensation. Research Communications in Chemical Pathology \& Pharmacology, 50, 379-384.

Arkhipchuk, V. V., Malinovskaya, M. V., \& Garanko, N. N. (2000). Cytogenetic Study of Organic and Inorganic Toxic Substances on Allium cepa, Lactuca sativa and Hydra attenuate Cells. Environmental Toxicology, 15, 338-344. http://dx.doi.org/10.1002/1522-7278(2000)15:4<338::AID-TOX10>3.0.CO;2-R

Babatunde, B. B., \& Bakare, A. A. (2006). Genotoxicity Screening of Waste Water from Agbara Industrial Estate, Nigeria Evaluated with the Allium cepa Test. Poll Results, 25, 227-234.

Barcelona, M., Gibb, J. P., Helfrich, J. A., \& Garske, E. E. (1985). Practical Guide for Groundwater Sampling (374 p). Ilinois State Water Survey ISWS Contract Report, Illinois.

Chauhan, L. K. S., Saxena, P. N., Sundararaman, V., \& Gupta, S. K. (1998). Diuron Induced Cytological and Ultrastructural Alterations in the Root Meristem Cells of Allium cepa. Pesticide Biochemistry and Physiology, 62, 152-163. http://dx.doi.org/10.1006/pest.1998.2379

Claaasen, H. C. (1982). Guidelines and Techniques for Obtaining Water Samples That Accurately Represent the Quality of an Aquifer (49 p). US Geological Survey Open File Report 82-1024.

Fawole, O. O., Yekeen, T. A., Ayandele, A. A., Akinboro, A., Azeez, M. A., \& Adewoye, S. O. (2008). Polluted Alamuyo River: Impacts on Surrounding Wells, Microbial Attributes and Toxic Effects on Allium cepa Root Cells. African Journal of Biotechnology, 7, 450-458.

Fiskesjö, G. (1993). The Allium Test in Wastewater Monitoring. Environmental Toxicology and Water Quality, 8, $291-298$. Http://dx.doi.org/10.1002/tox.2530080306

Fiskesjö, G. (1997). Allium Test for Screening Chemicals: Evaluation of Cytologic Parameters. In W. Wang, J. W. Gorsuch, \& J. S. Hughes (Eds.), Plants for Environmental Studies (pp. 308-333). Boca Raton, New York: CRC Lewis Publishers. http://dx.doi.org/10.1201/9781420048711.ch11

Godet, F., Babut, M., Burnel, D., Veber, A. M., \& Vasseur, P. (1993). The Genotoxicity of Iron and Chromium in Electroplating Effluents. Mutation Research, 370, 19-28. http://dx.doi.org/10.1016/S0165-1218(96)90123-8

Gömürgen, A. N. (2005). Cytological Effect of the Potassium Metabisulphite and Potassium Nitrate Food Preservative on Root Tip of Allium cepa L. Cytologia, 70, 119-128. http://dx.doi.org/10.1508/cytologia.70.119

Grant, W. F. (1982). Chromosome Aberration Assays in Allium. A Report of the United States Environmental Protection Agency Gene Toxicity Program. Mutation Research, 99, 273-291. http://dx.doi.org/10.1016/0165-1110(82)90046-X

Gupta, S. K., Gupta, R. C., \& Gupta, A. B. (2001). Recurrent Diarrhea in Children Living in Areas with High Levels of Nitrate in Drinking Water. Archives of Environmental Health, 56, 369-373. http://dx.doi.org/10.1080/00039890109604470

Ma, T.-H., Anderson, V. A., Harris, M. M., Neas, R. E., \& Lee, T. S. (1985). Mutagenicity of Drinking Water Detected by the Tradescantia Micronucleus Test. Canadian Journal of Genetics and Cytology, 27, 143-150.

Okonko, I. O., Adejoye, O. D., Ogunnusi, T. A., Fajobi, E. A., \& Shittu, O. (2008). Microbiological and Physicochemical Analysis of Different Water Samples Used for Domestic Purposes in Abeokuta and Ojota, Lagos State, Nigeria. African Journal of Biotechnology, 7, 617-621.

Olorunfemi, D. I., Ofomata, C. R., \& Alimba, C. G. (2013). Cytogenotoxicity Assessment of a University Borehole Water Supply Using the Allium cepa Test. Journal of Scientific Research and Development, 14, 25-34.

Olorunfemi, D. I., Okoloko, G. E., Bakare, A. A., \& Akinboro, A. (2011). Cytotoxic and Genotoxic Effects of Cassava Effluent Using the Allium cepa Test. Research Journal of Mutagenesis, 1, 1-9. http://dx.doi.org/10.3923/rjmutag.2011.1.9

Onokerhoraye, A. G. (1995). Urbanization and Environment in Nigeria: Implications for Sustainable Development. The Benin Social Science Series for Africa. Benin City: University of Benin.

Schneiderman, M. H., Dewey, W. C., \& Highfield, D. P. (1971). Inhibition of DNA Synthesis in Synchronized Chinise Hamster Cells Treated in G1 with Cyclohexamid. Experimental Cell Research, 67, 147-155.

http://dx.doi.org/10.1016/0014-4827(71)90630-6

Shugart, L. R., McCarthy, J. F., \& Halbrook, R. S. (1992). Biological Markers of Environmental and Ecological Contamination: An Overview. Risk Analysis, 12, 353-360. http://dx.doi.org/10.1111/j.1539-6924.1992.tb00687.x

Sia Su, G. (2005). Water-Borne Illness from Contaminated Drinking Water Sources in Close Proximity to a Dumpsite in Payatas, The Philippianes. J. Rural Trop. Pub.Hlth., 4, 43-48.

Sia Su, G. (2007). Impact on Drinking Water Sources in Close Proximity to the Payatas Dumpsite, Philippianes. Journal of Public Health, 15, 51-55. http://dx.doi.org/10.1007/s10389-006-0078-9 
Standard Organization of Nigeria (SON) (2007). Nigerian Standard for Drinking Water Quality (29 p). Abuja: Lome Street.

Turkoglu, S. (2007). Genotoxicity of Five Food Preservatives Tested on Root Tips of Allium cepa L. Mutation Research, 626, 4-14. http://dx.doi.org/10.1016/j.mrgentox.2006.07.006

United States Environmental Protection Agency (USEPA) (1996). National Recommended Water Quality Criteria-Correction: EPA 822/Z-99-001. Washington DC: USEPA.

World Health Organization (WHO) (2006). Guidelines for Drinking Water Quality Vol. 1. Geneva: World Health Organization.

World Health Organization (WHO) (2011). Guidelines for Drinking Water Quality (4th ed., 564 p). Geneva: World Health Organization.

Wright, J., Grungy, S., \& Conroy, R. (2004). Household Drinking Water in Developing Countries, a Systematic Review of Microbiological Contamination between the Source and Point Use. Tropical Medicine and Health, 8, 106-177.

Yassi, A., Kjellstrom, T., de Kok, T., \& Guidotti, T. L. (2001). Basic Environmental Health (456 p). New York: Oxford University Press, Inc. http://dx.doi.org/10.1093/acprof:oso/9780195135589.001.0001

Zhang, Y., \& Yang, X. (1994). The Toxic Effect of Cadmium on Cell Division and Chromosomal Morphology of Hordeum vulgare. Mutation Research, 312, 121-126. http://dx.doi.org/10.1016/0165-1161(94)90016-7. 